\title{
The Larval and Post-Larval Stages of the Pilchard, Sprat and Herring from Plymouth District.
}

\author{
By \\ Marie V. Lebour, D.Sc. \\ Naturalist at the Plymouth Laboratory.
}

With Figure; 1-12 in the Text.

THE young clupeoid material which had been collected from 1913 onwards and sorted out with a view to future biological study, especially of the Pilchard, was handed over to me by Mr. R. S. Clark with the main object of differentiating the three species Pilchard, Herring and Sprat. A research was therefore undertaken to find out the best way of distinguishing them through all their life history until metamorphosis. This was practically finished when the thesis by Fage (1920) on young clupeoids of the "Thor" expedition was published, rendering a large part of my work unnecessary, as, thanks to him, it is now almost impossible to mistake them at any period of their development, and they are clearly differentiated at any time in their life history.

My own observations have, however, brought out some interesting facts, and as they are entirely based on our local material it is interesting to compare them with those of Fage, which are based on material from the Mediterranean, the Channel, and the Atlantic, from the Bay of Biscay to the north of Scotland, including the Irish Sea.

The material here investigated and separated into species consists of all hauls with the Young Fish Trawl and tow-nets available up to the end of 1920, thus including Young Fish Trawl material captured by the Oithona 1913, 1914 and 1919 (Clark 1914, 1920, Allen 1917) and also 1920. Besides these there are a few scattered earlier hauls and separate specimens, notably one Young Fish Trawl haul (30.5.06) containing some thousands of young Sprats and a few Herring in late post-larval and metamorphosing stages. Finally, there are a few specimens from the tow-nets of various dates. A table showing all this material sorted into their species will be found at the end of the paper. 


\section{INTRODUCTION.}

The best distinguishing character is, as Fage points out, the number of myotomes which is characteristic for the species. Indeed, this is the only absolutely reliable character until the time of the appearance of the pelvic fins, that is to say, up to a length of $18 \mathrm{~mm}$. or more. Thus the usual number for the Pilchard is 51 to 52 , for the Sprat 46 to 48 , and for the Herring 56 to 58 , i.e. the number of myotomes equals the number of vertebræ, the small undeveloped myotomes running to the head in front of the vertebræ being disregarded.

In practice, however, it is difficult to count the myotomes at the tailend of the body, especially in the youngest forms, therefore I took the number from the back of the operculum to the anus, the "trunk" region of Fage, and this method was found to be perfectly satisfactory. In making these accounts it was found that the number of myotomes diminished between the operculum and anus as the fish grew. That is to say the anus was migrating forward over several myotomes. The position of the anus in all three species most certainly alters during the growth of the fish, the alteration being chiefly due to the larger growth of the region from the anus to the end of the caudal fin than of the region from the tip of the snout to the anus, as is shown very clearly by Fage (p. 14) in the Anchovy. Although, however, the actual migration of the anus over five to six myotomes is not nearly so large a factor in the alteration of its position on the body, this migration undoubtedly takes place and the alteration in the number of myotomes in the trunk region must be considered when using these for identification of the species.

The number of myotomes in the trunk does not exactly correspond with those from the first vertebra to the vertebra nearest the anus for two reasons.

Firstly, the operculum tends to cover the first myotome in fish from about $10 \mathrm{~mm}$. to about $25 \mathrm{~mm}$. in length, or more, after that it tends to cover two. The first myotome counted is thus one or two short in front.

Secondly, in the larger fish, from about $25 \mathrm{~mm}$. or more, the posterior myotomes slope more obliquely than those in front and overlap the vertebræ, so that there are one or two more myotomes in front of the anus than there are vertebræ (see Fig. 1).

The counts of the myotomes have been carefully checked by alizarin stained specimens to show up the vertebræ. The first vertebra counted is the first behind the head, the last the urostyle.

Bearing these facts in mind we may with safety take the number of whole myotomes in the trunk region as a reliable character, freely 
acknowledging that this number does not correspond to the vetebræ in the same region.

Thus in the Plymouth specimens the most frequent number in the Sprat is 37 dwindling to 31 , in the Pilchard 42 dwindling to 35 , and in the Herring 47 dwindling to $39 ; 31,35$, and 39 being the usual adult numbers. These numbers may vary slightly, but never overlap in the different species in fish of equal lengths. By means of stained specimens we find that the anus moves over $5-7$ vertebræ. The fact of the migration of the anus is emphasized here, because it is apparently disregarded altogether by previous writers, or deemed negligible compared with the undoubtedly larger growth of the tail region.

Besides the moving forward of the anus, and with it the anal fin, there is in all three species a forward migration of the dorsal fin, although

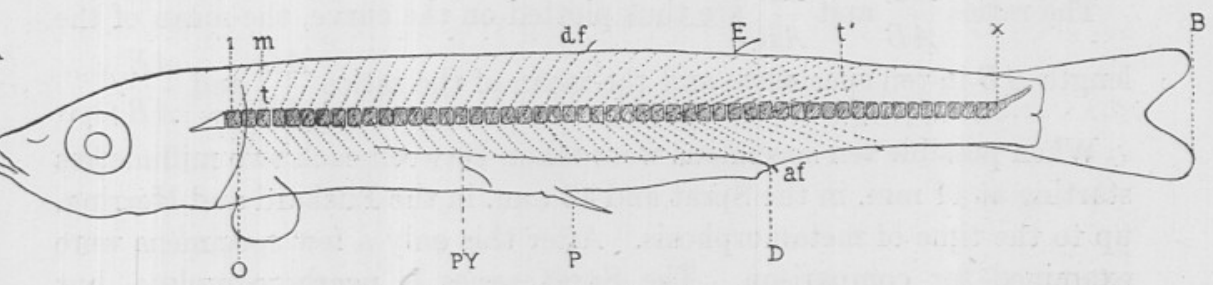

Fig. 1.-Diagram of Clupeoid. $A B$, length of body ; $A D$, snout to anus ; $A E$, snout to last ray of dorsal fin ; $O$, operculum ; $P$, pelvic fin ; d.f., dorsal fin ; a.f., anal fin; $I$, first vertebra; $X$, last vertebra (urostyle); $m$, first myotome counted ; $t . t^{1}$., first and last trunk myotomes counted from outside. (The myotomes are counted from the centre of the body.) $P Y$, pylorus.

In the diagram the fish has 52 vertebræ, and there are 35 whole myotomes in the trunk, i.e. between operculum and anus.

this is regarded by Fage as negligible in the Sprat. In the Pilchard this movement is large, the fin advancing over many myotomes (10-11) before it reaches its final resting-place, and in the Herring it is also large, although less than in the Pilchard. In the Sprat, however, the movement is much less apparent. There is, nevertheless, an undoubted movement in the front over 4-5 myotomes, the back of the fin only moving over 2 or 3. As there is little change in the position of the fin up to well over $25 \mathrm{~mm}$., the forward movement chiefly occurs close upon the time of metamorphosis. It is, however, quite insignificant compared with the increase of growth in the tail region, the region of the dorsal fin increasing little, whilst the front end of the body grows to a certain extent and the tail end grows a large amount. The explanation given by Fage as to the change of position in the dorsal fin agrees with my specimens in so far as he lays greater stress on the growth of the front and tail ends of the body, but he allows a movement of the front of the fin over only one myotome from 20 to $31.5 \mathrm{~mm}$., saying that it has not, so to speak, 
changed its place, whereas in my specimens at $32 \mathrm{~mm}$. the fin has moved forward in front over $3 \frac{1}{2}$ to $4 \frac{1}{2}$ myotomes, and he does not mention the movement of the anus over the myotomes in any of the species.

In order to show the change of position of the anus and dorsal fin I have prepared four curves and a diagram for each species. The curves are based first on the number of myotomes in the trunk region (i.e. from the end of the operculum to the anus), and secondly on the number of myotomes between the operculum and the last ray of the dorsal fin. The third and fourth curves are based on the relative lengths of the distance from the tip of the snout to the anus $A D$ (see text, Fig. 1) and the distance from the tip of the snout to the last ray of the dorsal fin $A E$, respectively, with the total length $A B$ (from the tip of the snout to the tip of the caudal fin).

The ratios $\frac{A D}{A B}$ and $\frac{A E}{A B}$ are thus plotted on the curve, the mean of the length $A B$ in ten specimens and the mean of the ratios $\frac{A D}{A B}$ and $\frac{A E}{A B}$.

When possible ten specimens were taken between each two millimetres starting at $11 \mathrm{~mm}$. in the Sprat and $13 \mathrm{~mm}$. in the Pilchard and Herring, up to the time of metamorphosis. After this only a few specimens were examined for comparison. The Sprat series is nearly complete, but gaps appear in the Pilchard series between $35 \mathrm{~mm}$. and in the Herring between $46 \mathrm{~mm}$. and the fully metamorphosed forms, also in some of the smaller Herring stages.

The last ray of the dorsal fin was used preferably to the first because the first ray is much later in appearing, but in the Sprat the front of the fin moves over more myotomes than the back, so that finally the whole fin occupies an area extending over two or three more vertebræ than it does at first. In the Pilchard and Herring the fin extends over an equal number throughout its migration.

The diagrams showing the migrations of fin and anus and their relations with the pelvic fins were taken from specimens stained with alizarin to show up the vertebræ. The smaller fish were mounted whole, the larger were bisected so as to leave the backbone and fins, and were then stained and mounted.

The number of vertebræ in the Plymouth specimens, chiefly counted in post-larval and adolescent specimens, is 47 to 48 in the Sprat, rarely 46 or $49,51-52$ in the Pilchard, rarely 50, 53, or 54; and 56-57 in the Herring, rarely 58 or 59 (see also for Herring, Orton, 1916).

The pelvic fins occupy a position relative to definite myotomes and vertebræ, and move slightly towards the dorsal fin as the fish grows, the front of the dorsal fin passing the pelvics in the Pilchard and Herring, but remaining behind them in the Sprat. This movement is regarded 
-by Fage as entirely due to alteration in the abdominal cavity, as in the Pilchard and Sprat the position of the fins is always in the vicinity of a particular rib, the 15th. This is undoubtedly the case in all the Plymouth speeimens also, the movement taking place over a space equal to two or three myotomes.

The first ray of the dorsal fin is in all three species very small, and

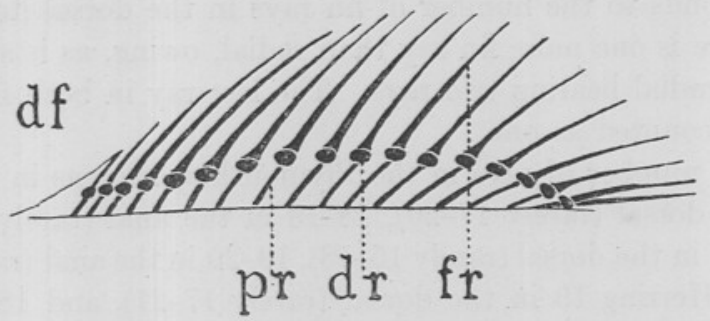

Frg. 2.-Diagram of dorsal fin, d.f., of a post-larval clupeoid; p.r., proximal radials; d.r., distal radials ; f.r., fin rays.

only comes up at about $25 \mathrm{~mm}$. in the Sprat, and still later in the Pilchard and Herring. In any case, it is so small that it makes little difference in front of the fin with regard to the myotomes.

In both dorsal and anal fins there are three series of elements which may be termed the proximal radials, distal radials, and fin rays (Figs. 2-3). The first to appear are the proximal radials, which are simple rods

\section{af}

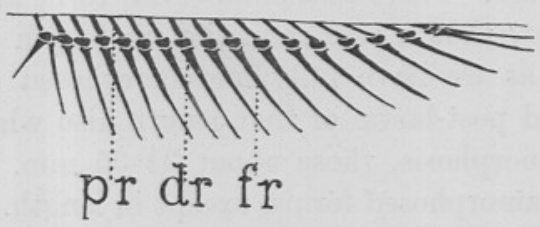

FIG. 3.-Diagram of anal fin, a.f., of a postlarval clupeoid; p.r., proximal radials ; d.r., distal radials; f.r., fin rays.

projecting slightly from the body. Those in the centre are the first formed, next those behind from the centre backwards, and lastly those in front from the centre forwards. In this way the first radial is the last to be formed. The distal radials form next and consist of small knobs above the proximal radials. These form in the centre, whilst the hind and front proximal radials are forming, so that some are present before the full number of proximal radials is complete. The distal radials also arise from the centre backwards and forwards, the last to be formed being those in front. Finally the fin rays appear, which consist of rods 
fitting on to the distal radials. The central fin rays form first, and may be present before either the proximal or distal radials are complete, those at the hind end forming next from the centre backwards, and, lastly, those in front. In the older post-larvæ the rays are jointed, except the first two which are shorter than the others and in the anal fin spring from the same radial. The number of proximal and distal radials is equal and corresponds to the number of fin rays in the dorsal fin, but in the anal fin there is one more fin ray than radial, owing, as is stated above, to the first radial bearing two rays. The last ray in both fins is double and is here counted as one.

The usual number of rays in the Plymouth specimens in the Pilchard is 18 in the dorsal (rarely 17-20), 18-19 in the anal (rarely 17-21); in the Sprat 17 in the dorsal (rarely 15-18), 19-20 in the anal (rarely 18-21); and in the Herring 19 in the dorsal (rarely 17-21), and 18 in the anal (rarely 15-19).

During larval and post-larval growth the various parts of the body are all growing in definite proportions, but during the time of metamorphosis, as Fage shows clearly (and the fact is borne out in the Plymouth specimens), there is an almost complete cessation of growth in the trunk region, the head and tail only growing in any marked degree. During this period the scales are indicated, pyloric cœca formed, and adult colouring begun, until at last the completely scaled fish appears. This cessation of growth in the trunk region accounts for the fact that some of the metamorphosed forms are of the same length as some of the postlarvæ, but of different proportions, the head especially being much larger in the former. There seems, however, to be an indication, at any rate in the Sprat, that a real reduction in length takes place also at metamorphosis, as we have fully metamorphosed specimens as small as $30.5 \mathrm{~mm}$., and post-larvæ of that length also which are a very long way from metamorphosis, those about 34-35 $\mathrm{mm}$. being much nearer to the small metamorphosed forms, except in length.

In comparing our specimens with those of Fage there is a distinct indication that our post-larval Pilchards are slightly more backward for the same length than those of the Mediterranean, the Herring slower* in development than those from the north of Scotland (this latter agreeing with Fage's observations), and the Sprat, although in some respects slightly more forward in its younger stages than those from the north of Scotland yet staying longer in its later post-larval stages; specimens of $41 \mathrm{~mm}$. occurring which have not completed their metamorphosis.

* The term slower is here and elsewhere in the paper used not in the sense of time, but as being more backward in development at the same length. 


\section{THE PILCHARD.}

\section{Sardina (Clupea) Pilchardus (Walb.)}

The main spawning of the Pilchard occurring in the Plymouth area is further out to sea than that of the Sprat and Herring, particularly in the region of the Eddystone. The earliest record is April 2-3, 1920, 8 miles S.E. of the Eddystone, when a large quantity of Pilchard eggs were caught at night and young hatched from them.* The latest record is November 26th, 1913, of a young Pilchard $11 \mathrm{~mm}$. long. The breeding season certainly (Clark, 1920) extends from April to October, maximum June to August. The very young Pilchards may be brought close to the shore; one from the tow-nets, West Channel, 27.4.20, measured $5 \mathrm{~mm}$., still with a yolk sac. Post-larval stages (18 to $32 \mathrm{~mm}$.) were collected by Dr. Orton (October, 1919) in Millbay Docks, and three specimens (30-35 mm.) were obtained from Salcombe Harbour. Postlarval stages between 10 and $30 \mathrm{~mm}$. occur abundantly in the Young Fish Trawl hauls and occasionally in the tow-nets all through the summer. In following up the biology of the Pilehard Mr. Clark has been successful in capturing large numbers of adolescent Pilchards mixed with Sprat and Herring in September and October, 1920, in the Plymouth estuaries and also close inshore in the bays. These were fully scaled and ranged from 39 to $90 \mathrm{~mm}$.

Unfortunately there is a large gap in the material from the postlarval stage at $35 \mathrm{~mm}$., and the smallest scaly forms of $38 \mathrm{~mm}$., the length at metamorphosis probably being $40-50 \mathrm{~mm}$. or more.

The eggs measure 1.5-1.9 mm., and both these and the early larval stages from Plymouth have been described and figured by Cunningham (1889-1894), who draws attention to the larval sense papillæ along the sides of the body, which are similar to those in the Sprat here figured (Fig. 7). The embryo, just before hatching, and the newly hatched young in all specimens examined by me were pigmented freely with small. black chromatophores on the head and dorsal surface. This pigment is not figured by Cunningham, who says his newly hatched young were without pigment except for a few black chromatophores in the dorsal region of the body. The figures given here (Fig. 4) were taken from specimens brought in as eggs and hatched in glass jars in the Laboratory. The larval pigment very soon disappears and small chromatophores, similar to those described by Fage, below the notochord occur instead.

* Sizce sending this to press Pilchard eggs nearly ready to hatch were taken in the West Ch «nnel, March 17th, 1921 .

NeW SERIEs.-Vol. XII. No. 3. September, 1921. 
The newly hatched larva is $3 \cdot 3$ to $3.5 \mathrm{~mm}$. long and loses its yolk sac at about $5.5 \mathrm{~mm}$. A specimen $7.5 \mathrm{~mm}$. showed 4 proximal radials in its dorsal fin, which is interesting as Fage's Mediterranean specimens of $7.2 \mathrm{~mm}$. showed no trace of fin at all. In other respects, however, the young from Plymouth seem further backward. Fage found no difference in the post-larvæ from the Atlantic, the Channel, and the Mediterranean, but I find that our specimens develop more slowly than the Sprat with regard to the unpaired and pelvic fins and the tail, whilst Fage found the reverse to be the case, and the pelvic fins are certainly longer in appearing than in the Mediterranean forms. Thus generally speaking
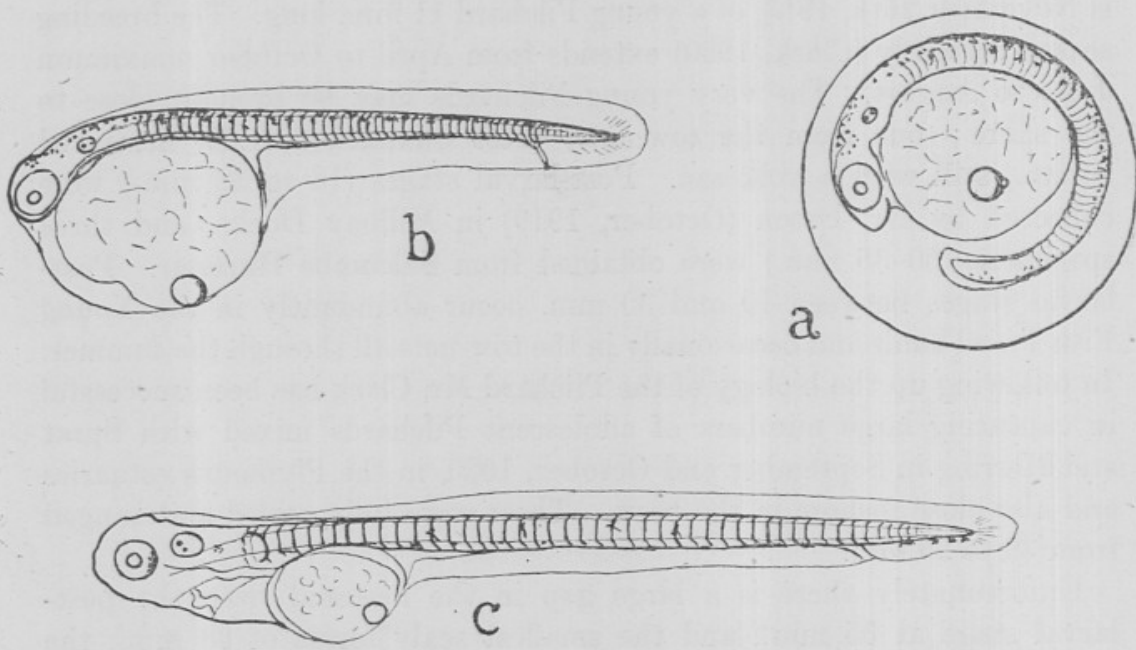

FiG. 4.-Egg and newly hatched young of Pilchard; $\lceil\alpha .$, cgg of Filchard nearly reedy to hatch, $1.8 \mathrm{~mm}$; $b$., newly hatched Pilchard, $3.3 \mathrm{~mm}$. (hatched in Aquarium); $c$, Pilcherd 7 days old, $5 \mathrm{~mm}$. (hatched in Aquarium). All frcm eggs, tow-net, April 2-3, 1920, 8 miles S. of Eddystone.

the notochord remains straight at a greater length than the Sprat, and, although it usually begins to turn up after $11 \mathrm{~mm}$., may remain straight up to $12.5 \mathrm{~mm}$., whilst in the Sprat it is always turned up to a certain extent at $11 \mathrm{~mm}$. The dorsal and anal fins are also usually further advanced in the Sprat than in the Pilchard of the same length, and, more important still, the pelvics do not appear at $18 \mathrm{~mm}$., as they do in Fage's specimens, but at 20-22 mm., whereas they appear in the Sprat from $17 \cdot 25$ to $20 \mathrm{~mm}$. As soon as they appear the difference in position is at once noticeable, as, although they are in both species at their origin on a level with the 18th myotome, yet in the Sprat the pelvics are separated from the pylorus by a space equal to at least $2 \frac{1}{2}$ to 3 myotomes, whereas in the Pilchard the pelvics originate on a level with the pylorus, a character rightly regarded by Fage as an unfailing distinction between 
the two species. The position of the pelvic fins is further forward on the body than in the Sprat and the Herring.

The Plymouth specimens are thus rather slower in development than, at any rate, those of the Mediterranean. The dorsal fin is complete

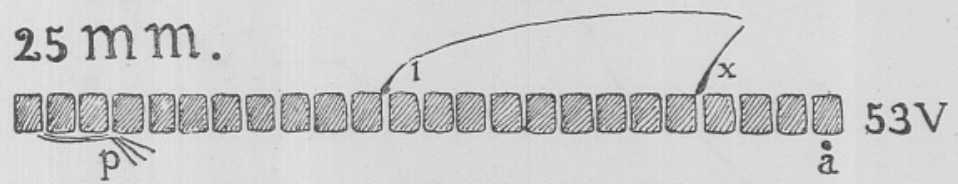

181920212223242526272829303132333435363736394041
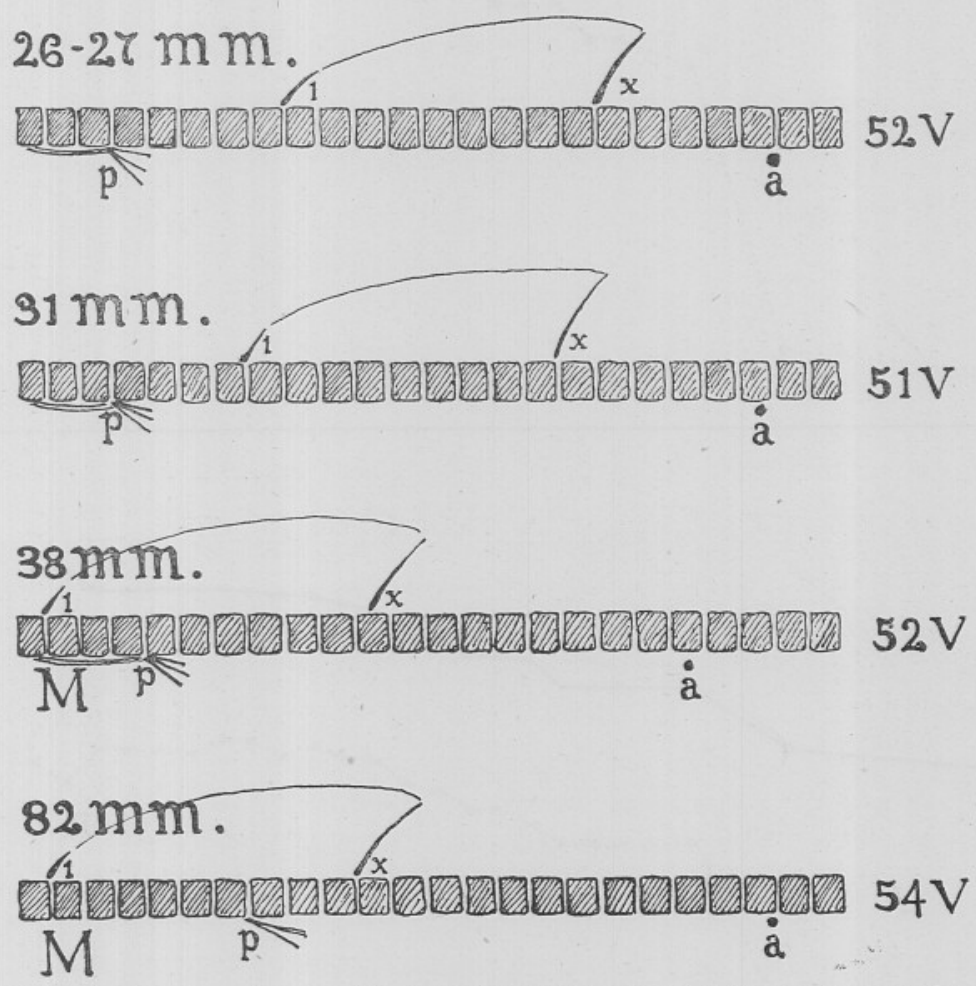

FIG. 5.-Diagram showing the relations of the fins and anus to the vertebræ in the Pilchard at various lengths ; $p$., pelvic fins ; $1-x$., first and last ray of dorsal fin ; $a$., anus; $v$., vertebræ ; $M$. , metamorphosed specimens.

except for the first ray at 21 to $25 \mathrm{~mm}$., the last ray coming up at about $26 \mathrm{~mm}$., the anal fin being completed a little later.

In other respects the Plymouth specimens agree with Fage's very closely. At the time of appearance of the pelvic fins the dorsal fin has not begun to move forward ; its first apparent ray (in reality the second) is usually in the neighbourhood of the 27th-28th myotomes and stands 


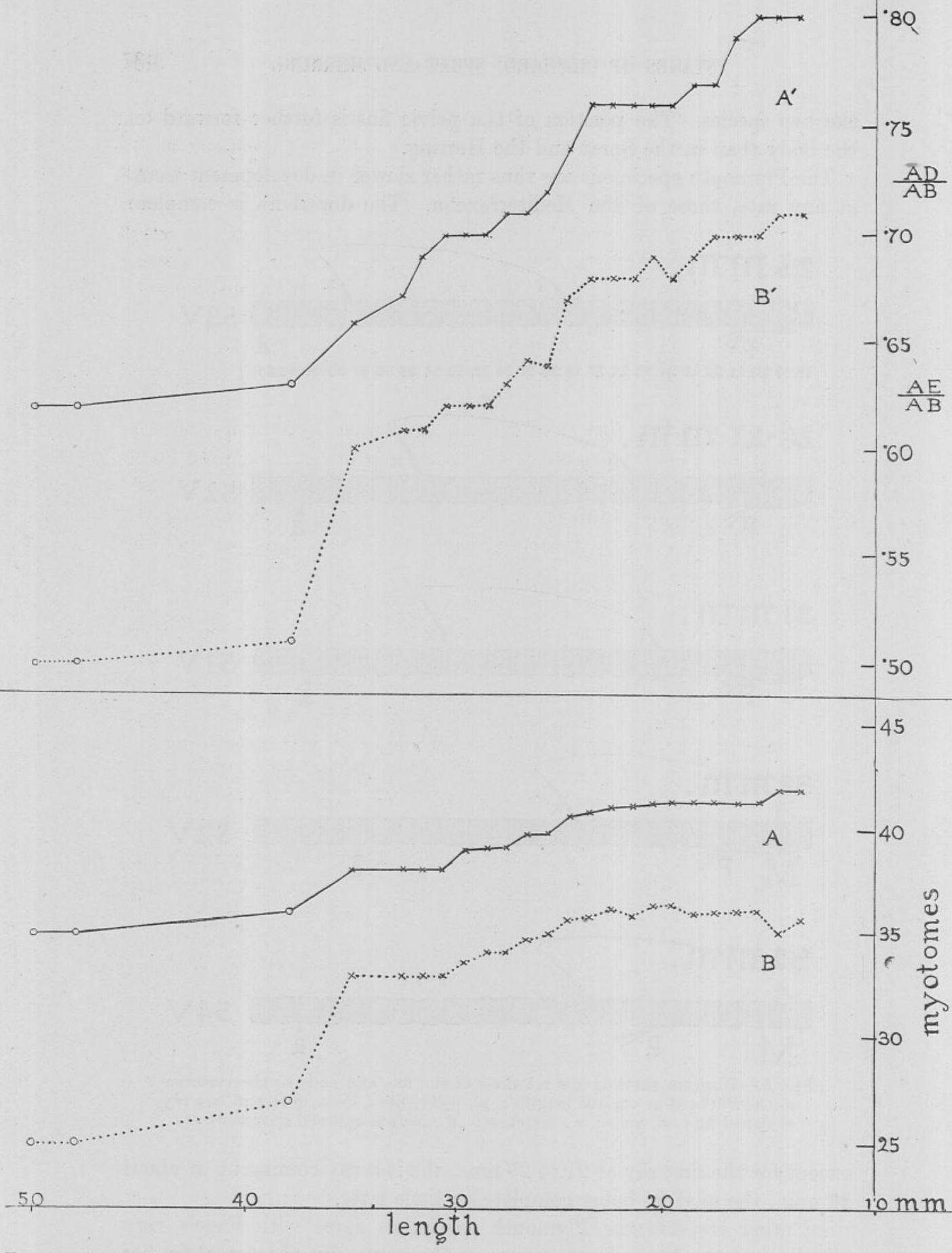

FrG. 6.-Curves showing the change of position of dorsal fin and anus in the Pilchard; $A$, showing number of myotomes in the trunk in Pilchards 13 to $50 \mathrm{~mm}$. long; $B$, showing number of myotomes between operculum and last ray of dorsal fin in the same specimens; $A^{1}$, showing ratio of distance from snout to anus $(A D)$ and body length $(A B)$ in the same specimens; $B^{1}$, showing ratio of distance from snout to last ray of dorsal fin $(A E)$ and body length in the same specimens; $o=$ metamorphosed specimens. Correction for curve $A$ (approximate) to show true number of myotomes from head to anus. $+=$ myotomes covered by operculum, $-=$ myotomes overlapping anus : -13 to $23(+1), 23$ to $27(+1-1$ or 2$), 27$ to 35 and metamorphosed forms $(+2-2)$. Cf. page 437 . 
above the division between the 28 th and 29 th vertebræ, its last ray being above the division between the 37 th and 38 th. There are usually $36-37$ myotomes in front of the last ray ( 35 or 36 from the operculum to the ray) and 42 in front of the anus (41 from the operculum to the anus). The pelvics originate as small thickenings 10 or 11 myotomes in front of the dorsal fin, under the 18th-19th vertebræ, the rays of the pelvics originating under the 21 st vertebra (Fig. 5). These positions are very regular and vary little in specimens of the same size and until the fins begin to move. The proportions of the body agree very well with those given by Fage, and, except for the slowness in development of the fins differ hardly at all.

The anus is moving forward slowly relative to the myotomes, but the dorsal fin has not yet begun its migration. However, the position of both fin and anus is gradually coming further forward on the body because the tail region from the anus to the tip of the caudal fin is growing faster than the rest of the body. The curve (Fig. 6) shows that the ratio $\frac{A D}{A B}$ has changed from $\cdot 80$ to $\cdot 76$ in a fish $16 \mathrm{~mm}$. to $20 \mathrm{~mm}$., and the ratio continues to decrease up to $35 \mathrm{~mm}$., when it is at 66 . Here our post-larval specimens stop, but most certainly it continues after that, for in the smallest metamorphosed specimen of $38 \mathrm{~mm}$. it is at $\cdot 63$, and it remains between .62 and .63 in the larger metamorphosed forms. The anus thus attains its permanent position shortly before metamorphosis. Unfortunately, we have none of these intermediate specimens. Judging from Fage's observations where he finds metamorphosis takes place from 35 to $45 \mathrm{~mm}$., and since at $40 \mathrm{~mm}$. his specimens are still at the stage when the pelvic fin is in front of the dorsal, it is highly probable that our specimens would metamorphose as late as $40-50 \mathrm{~mm}$., and that the smallest metamorphosed specimens have undergone a reduction in length.

The anus migrates usually from the region of the 43rd to the 37 th vertebra, but may stop at the 39 th in specimens with 54 vertebræ. Indeed, in all there may be a variation of a vertebra or two owing to the corresponding variation of total vertebræ in the body. The usual extent of the migration is thus over $5-6$ vertebræ. Finally there are 35-36 myotomes to be counted between the operculum and anus, two of which have overlapped from behind, but as the operculum covers two the resulting number is the same as the true number of myotomes from head to anus. This I have represented at the foot of the Table as 35 or $36+2-2$.

It is easy to see at a glance that the movement over at the most $5-6$ vertebræ is but a very small factor in the alteration in position of the anus. As an illustration we may take the following measurements of 
young Pilchards $13 \cdot 5-38 \mathrm{~mm}$. long. $A B=$ length, $D=$ position of anus, $\delta=$ the imaginary position of the anus when corrected for shift in position :

$\begin{array}{lllll}A B & A D & D B & D \delta & \frac{A-\delta}{\delta-B} \\ 13.5 & 10 \cdot 75 & 2 \cdot 75 & 0 & \frac{10 \cdot 75}{2 \cdot 75}=3 \cdot 9 \\ 24 \cdot 5 & 18 \cdot 25 & 6 \cdot 25 & 0 \cdot 75 & \frac{19}{5 \cdot 5}=3 \cdot 5 \\ 35 & 23 & 12 & 1 \cdot 75 & \frac{24 \cdot 75}{10 \cdot 25}=2 \cdot 4 \\ 38 \text { (met.) } & 24 & 14 & 2 & \frac{26}{12}=2 \cdot 2\end{array}$

The ratio $\frac{A \delta}{\delta B}$ decreasing showing that the distance $\delta B$ increases proportionally more than the distance $A \delta$.

The migration of the anus begins at about $16 \mathrm{~mm}$., but the dorsal fin does not begin to move over the myotomes until about 22 to $25 \mathrm{~mm}$., beginning with its front ray over the 29 th vertebra, and its hind ray over the $38 \mathrm{th}$. In a specimen of $25 \mathrm{~mm}$., with 53 vertebræ the first and last rays are between the 28th and 29th, and the 37 th and 38 th, respectively, the rays of the pelvic fins under the 21st, their origin under the 18 th. In a specimen $26-27 \mathrm{~mm}$., with 52 vertebræ they are between 25-26 and 34-35, the pelvies in the same position as before. The fin is thus moving gradually forward. At $31 \mathrm{~mm}$., the front and back rays are between $24-25$ and $33-34$, the pelvies as before, and at $35 \mathrm{~mm}$. the same. Here, unfortunately, our specimens stop until we get small metamorphosed forms. The smallest metamorphosed specimen measures $38 \mathrm{~mm}$., has 52 vertebræ, the front ray of the dorsal well in front of the pelvic fins, between the 18th and 19th vertebræ, the last ray over the 28 th, the pelvic rays between 21 and 22 , their origin still under the 18 th. The dorsal fin has thus performed a migration forward over at least 10 vertebræ, the pelvies having moved backward over one. In still older specimens the pelvics have moved over three more, the origin having also moved, the dorsal fin in a specimen of $82 \mathrm{~mm}$. being in the same position as at 38 , but some metamorphosed specimens have it one vertebra further forward, and Fage has shown that it only stops at $106 \mathrm{~mm}$. when it lies in the region of the 16 th myotome. The movement of the dorsal fin and pelvic fins thus continues after metamorphosis, but only to a very small extent with regard to the dorsal fin compared with its movement between $35 \mathrm{~mm}$. and metamorphosis.

The position of the dorsal fin is thus largely influenced by its migration 
over many vertebræ and myotomes, the larger growth of the tail portion of the body compared with the fore part also taking its part.

Although my own specimens show a large and important gap between post-larval forms of $35 \mathrm{~mm}$. and fully metamorphosed forms beginning at $38 \mathrm{~mm}$., yet the observations of Fage fill in these gaps to a great extent, although being from a different locality the comparison cannot be strictly accurate.

$\mathrm{He}$ finds that at $40 \mathrm{~mm}$. the specimens are still in the process of metamorphosis, having the pelvic fins still in front of the dorsal, and he regards the metamorphosis as taking place between 35 and $45 \mathrm{~mm}$. As our specimens are slower in development it is probable that metamorphosis would take place in these at about $40-50 \mathrm{~mm}$. My specimen of $35 \mathrm{~mm}$. is so far backward in development that a glance at the curve will show how far from metamorphosis it is if only the dorsal fin be taken into account, but besides this the anus has not finished its migration, the pelvics are 4 vertebræ in front of the dorsal fin, and the body is thin and narrow, with a small head without any sign of a near metamorphosis. When we compare this with our metamorphosed form of $38 \mathrm{~mm}$. with fully scaled, silvery, plump body, large head, anus in the adult position, and dorsal fin and pelvies having very nearly finished their migrations, we cannot help believing that this latter specimen has come from a post-larval fish of greater length, and that a reduction of a few millimetres has taken place at the time of metamorphosis, besides the cessation of growth in the trunk region described by Fage.

The method of growth in the Plymouth Pilchards agrees with Fage's observations. Thus in the post-larval forms the increase in length in the trunk is equal to that of the head and tail together, that of the metamorphosed forms the same. The much greater length of the head and tail in proportion to the body in the smallest metamorphosed forms makes it almost certain also that there is that cessation of growth in the trunk region during the period of metamorphosis, which is proved by Fage, but the absence of specimens during these stages makes these observations impossible with ours.

\section{THE SPRAT.}

\section{Clupea Sprattus L.}

The eggs of the Sprat may begin to appear in January and are usually very abundant in February and March in Plymouth Sound, often close to the shore, but also beyond the Breakwater in the region of the Knap and Panther buoys and the Mewstone. They dwindle after that, so that very few are found in May and after, although they occur as late as 
July (Hefford, 1910), and a young specimen of $6 \mathrm{~mm}$. has been obtained in November.

The eggs measure 0.96 to $1.08 \mathrm{~mm}$. across.

Just before hatching the young Sprat is speckled with black on its head and dorsal surface, and it is hatched whilst still possessing this larval pigment at about $3 \mathrm{~mm}$. A noticeable feature in these newly hatched young are the lateral sense papillæ along the sides of the body, about six on each side, placed alternately and not opposite to one another
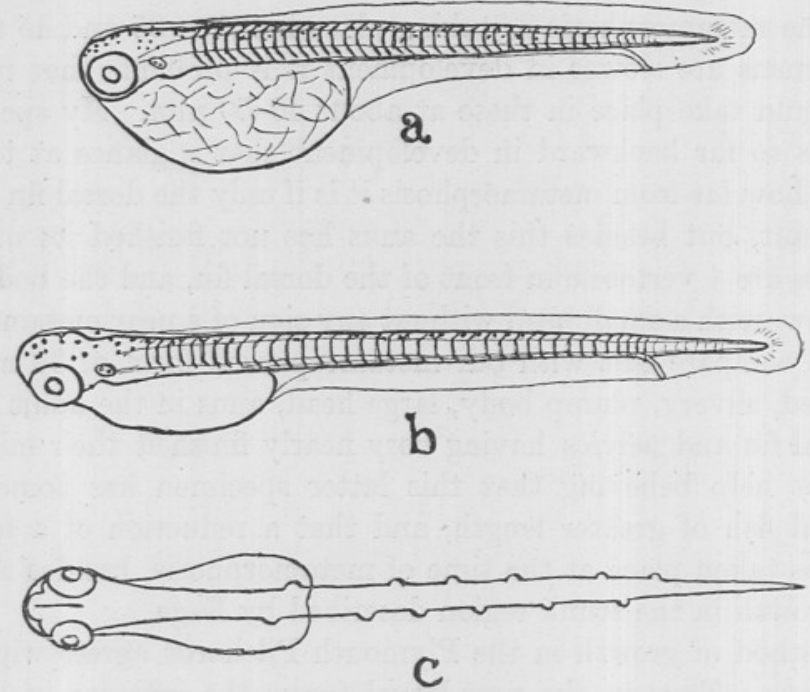

FIG. 7.-Newly hatched young of Sprat ; $a$., just hatched in bowl in Aquarium, $3 \mathrm{~mm}$., from egg from tow-net, Breakwater $3.5 .20 ; b$, another specimen hatched in bowl, probably 2 days old, $3.5 \mathrm{~mm}$., from egg from tow-net, Breakwater, 27.1.20; c., the same specimen, ventral view, showing senscry papillæ.

(Fig. 7). These are similar to those described and illustrated by Cunningham in the Pilchard. At $3.5 \mathrm{~mm}$. the dorsal speckles have almost disappeared and the yolk sac dwindles until at $5 \mathrm{~mm}$. both yolk sac and first larval pigment has gone, the eye becomes pigmented and the usual chromatophores along the alimentary canal appear.

From February to May young Sprats are found abundantly in the tow-nets and rather larger specimens later on through the summer, the largest haul being one from Whitsand Bay in June, 1906, consisting of thousands of Sprats from 25 to $41 \mathrm{~mm}$., the largest not having finished their metamorphosis and still in the transparent stage. Very few were taken in the autumn, except those that were fully metamorphosed and scaly, which occur in enormous numbers all round the coast close inshore. 
The researches of Fage have been made on a large number of young Sprats, from 4 to $35 \mathrm{~mm}$., taken from the west of the British Islands, the Channel, and the northern part of the Bay of Biscay. Those from the Channel being from much the same waters as ours, but most of them small, the largest being $30 \mathrm{~mm}$.

The chief fact that strikes one when examining the Plymouth specimens is the variability as to development, so that it is very difficult to fix a certain length for certain features to be present. Generally speaking up to about $20 \mathrm{~mm}$. they agree with Fage's description and figures. $\mathrm{He}$ points out that the very young stages after the loss of the yolk sac resemble those of the Pilchard very closely, and that the only safe guide is the number of myotomes, that the pelvic fins begin to appear at $18 \mathrm{~mm}$., and that they are separated from the pylorus by a space (unlike the condition in the Pilchard, where the pelvics originate close up to the pylorus). The position of the pelvies, with regard to the pylorus, shows well in all the Plymouth specimens, and forms a good distinguishing character from the time of the appearance of the pelvic fins. In our specimens the fins appear at the earliest at a length of $17 \cdot 25 \mathrm{~mm}$., at the latest at $20.25 \mathrm{~mm}$., the $18 \mathrm{~mm}$. given by Fage being a good average size, but compared with the Pilchard they arise earlier and as a general rule the Sprats are further forward for the same length than the Pilchards of this district. In the Pilchards here they seldom show as early as $20 \mathrm{~mm}$., and may be absent at $22 \mathrm{~mm}$. Thus, agreeing with Fage, in the Plymouth Sprats at $20 \mathrm{~mm}$., the "tail" as defined by him (i.e. the portion of the body from the anus to the base of the caudal fin), has grown longer and measures rather more than $\frac{1}{6}$ of the total length, the pelvics have no rays and are inserted almost exactly in the centre of the trunk in the region of the 18th myotome with the pylorus well in front of them. The dorsal fin has its first apparent ray (in reality the second) in the region of the 26 th myotome, and its distance from the head is contained $1 \frac{2}{5}$ in the length of the trunk. At this stage Fage states that all the rays in the dorsal and anal fin have appeared. In my specimens all the dorsal radials are present, but not the first ray, and the anal fin has all its elements except the first two rays. Seventeen is the usual number of dorsal rays (rarely 16 or 18), all but the first being formed by about $16 \mathrm{~mm}$., the last being formed as early as $11 \mathrm{~mm}$. The anal fin has usually 19-20 rays, one more ray than radials, all of which, except the first two, are present at $16 \mathrm{~mm}$.

It is at this time, from about $20 \mathrm{~mm}$., that the Sprat is so variable in its development. The head now tends to become longer, and the tail longer, but from 20 to $25 \mathrm{~mm}$. or more it may either become much stouter with a longer head and tail compared with the body length, or it may stay in the slender larval form with its head still about $\frac{1}{7}$ of the 
total length. On the whole the long slender form predominates, which is still so like the Pilchard, the head thus beginning to grow longer from 22 to $26 \mathrm{~mm}$.

It was found that at $25 \mathrm{~mm}$. in a specimen with 48 vertebræ the

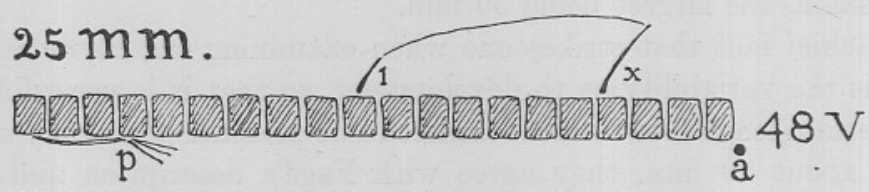

$1819202122232425262728293031 \quad 323334 \quad 35 \quad 3637$
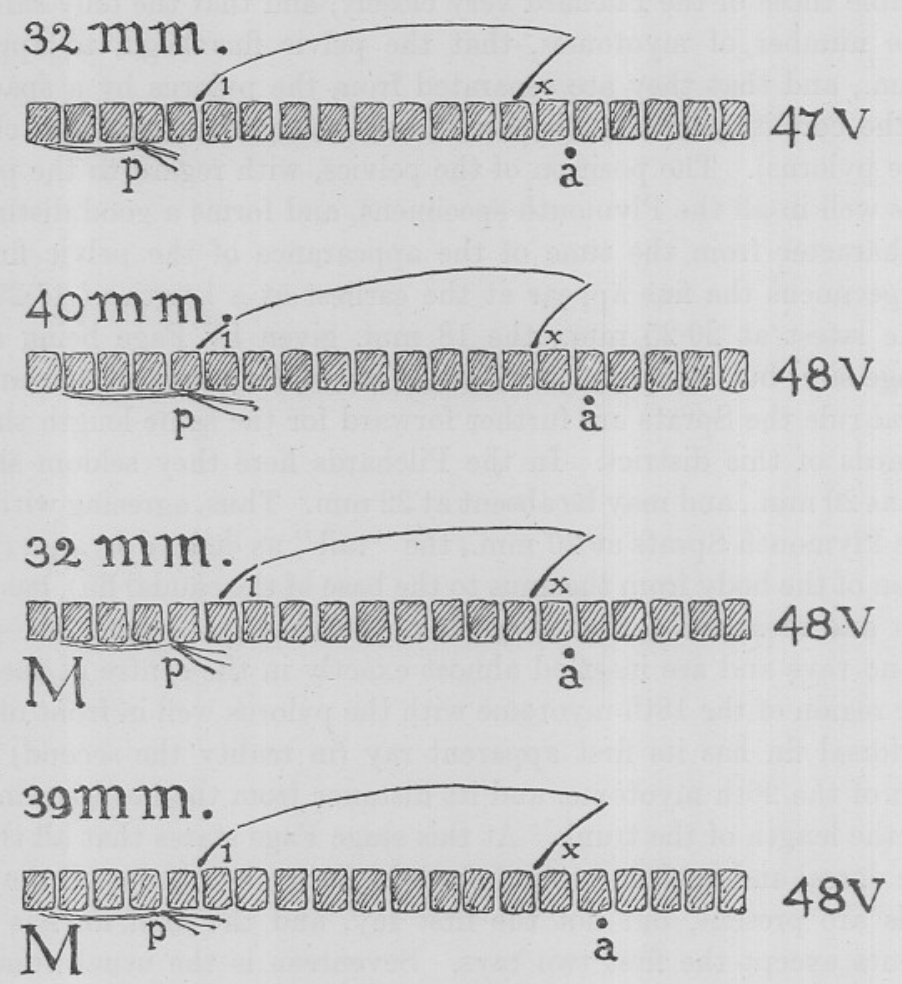

Fig. 8.-Diagram showing the relations of the fins and anus to the vertebræ in the Sprat of various lengths ; $p$., pelvic fins ; $1-x$., first and last ray of dorsal fin ; $a$., anus ; $v$., vertebræ ; $m$., metamorphosed specimens.

pelvics had their origin under the 18 th vertebra in connection with the 18th myotome, but the actual rays began under the 21 st vertebra in connection with the 20 th myotome (Fig. 8 ). The first ray of the dorsal fin was between the 26th and 27 th vertebræ or over the 27 th in connection with the 26 th or 27 th myotome, the last ray over the 34 th 
vertebra in connection with the 33rd myotome and the anus between the 37 th and 38 th vertebræ. Slight variations might occur in the numbers owing to the difference in vertebræ, but as a rule they are very constant.

At $32 \mathrm{~mm}$. the position of the pelvics is practically the same, but the first dorsal ray has advanced to between the 22 nd and 23 rd vertebræ, which is the usual position in the metamorphosed forms, the last ray standing over the 31 st vertebra (in this case the fin is rather far forward owing to there being one vertebra less). In a specimen of $40 \mathrm{~mm}$., not yet metamorphosed and having 48 vertebræ, the first ray was between the $22 \mathrm{nd}$ and $23 \mathrm{rd}$ and the last between the $31 \mathrm{st}$ and $32 \mathrm{nd}$, the anus being under the 33rd. The pelvics have slightly changed their place, so that although the origin is as before, the rays begin under the $22 \mathrm{nd}$ vertebra and are only half a vertebra from the first ray of the dorsal.

We thus see that from 25 to $40 \mathrm{~mm}$. the dorsal fin has advanced in the front over 4-5 vertebræ, the back only having advanced $2-3$, the fin having grown in length so as to overlap two more vertebræ than when the full number of rays first appeared. The rays of the pelvic fins have slightly altered their position and are nearer the dorsal fin, and the anus has moved forward over $4-5$ vertebræ. In the metamorphosed specimens of 33 and $39 \mathrm{~mm}$. the positions are much the same, the fin and anus having accomplished the amount of migration necessary to bring them to the adult position relative to each other and to the pelvics at from 32 to $41 \mathrm{~mm}$.

The accompanying curve (Fig. 9) shows the number of myotomes in the trunk region and in the distance between the operculum to the last ray of the dorsal fin in Sprats, from 11 to $41 \mathrm{~mm}$. Starting at 11-12 $\mathrm{mm}$. there are 37 myotomes in the trunk region which are reduced to 30-31 slightly before the time of metamorphosis, and between the operculum and the last ray of the dorsal fin there are 32 myotomes which are reduced to $28-29$, the last ray of the fin thus usually passing over 2-3 myotomes only. The anus begins to change its position with regard to the myotomes almost at once, but the dorsal fin does not change at its hind end until it reaches about $30 \mathrm{~mm}$., although the front end begins between 25 and $30 \mathrm{~mm}$. and passes over 4-5 myotomes.

The position of both fin and anus is, however, influenced to a much greater extent by the growth of the abdominal region and tail, especially the latter, while the hind end of the trunk grows very little, and in this way the fin and anus come to lie nearer the head. This change of position is shown in curves II $A^{1}$ and $B^{1}$. The ratio $\frac{A D}{A B}$ gradually lessens from .80 to $\cdot 61$, and the ratio $\frac{A E}{A B}$ lessens from $\cdot 71$ to $\cdot 59$. The change is 


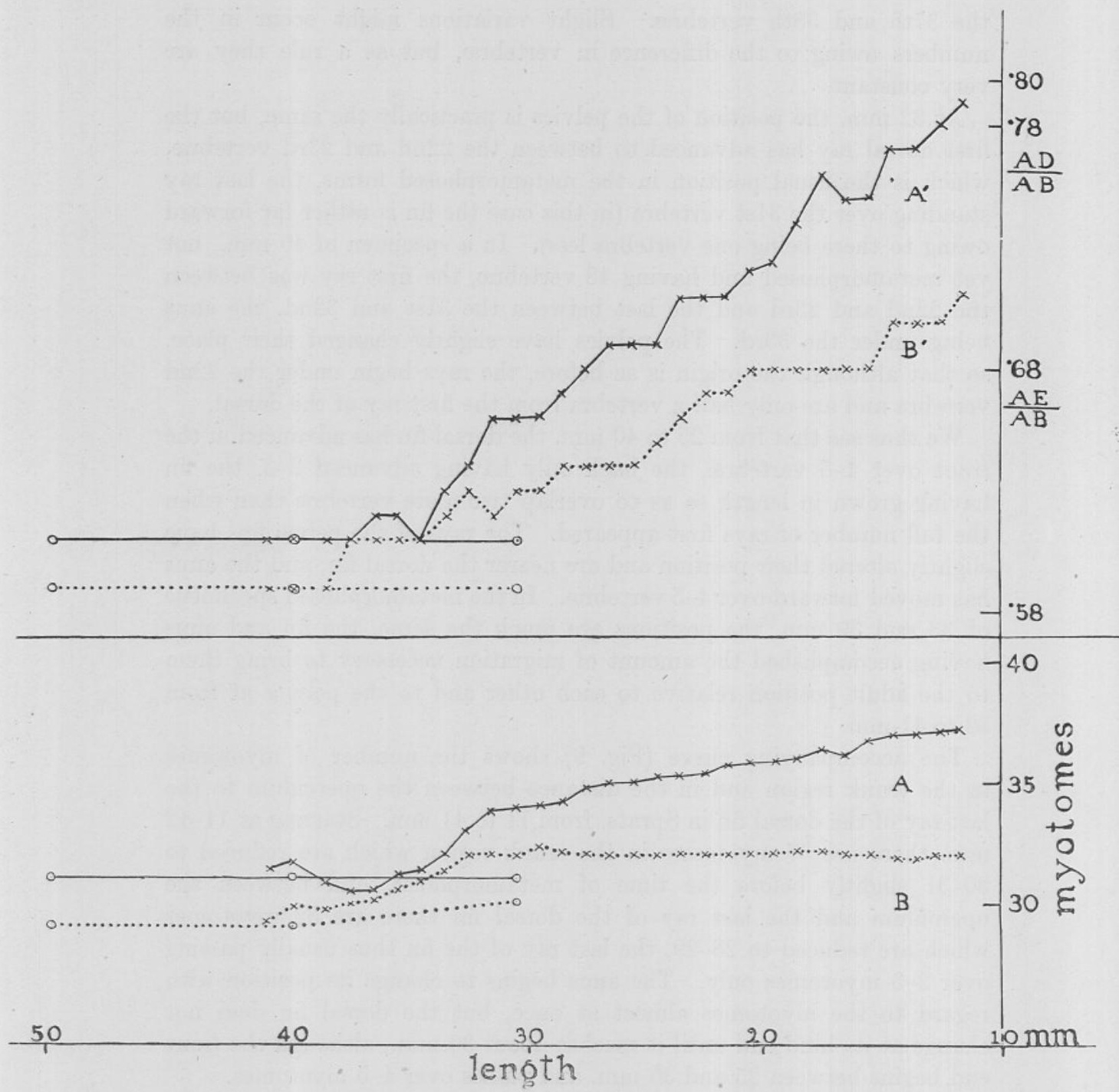

Fic. 9.-Curves showing the change of position of the dorsal fin and anus in the Sprat. $A$, showing number of myotomes in the trunk in Sprat, $11 \cdot 5-50 \mathrm{~mm}$. long; $B$, showing number of myotomes between operculum and last ray of dorsal fin in the same specimens; $A^{1}$, showing ratio of distance from snout to anus $(A D)$ and body length $(A B)$ in same specimens; $B^{1}$, showing ratio of distance from snout to last ray of dorsal fin $(A E)$ and body length in same specimens; $o=$ metamorphosed specimens. Correction for curve $A$ (approximate) to show true number of myotomes from head to anus. $+=$ myotomes covered by operculum, $-=$ myotomes overlapping anus : -11 to $25(+1), 25$ to $33(+1-1$ or -2$), 33$ to 41 and metamorphosed forms $(+2-2)$. 
greater in $\frac{A D}{A B}$, but the reduction starts in both at 11-12 mm., whereas the movement of the fin over the myotomes takes place later.

There is thus undoubtedly a change of position in the dorsal fin so that it lies further forward in the metamorphosed Sprat than it does in the larval and post-larval forms. This is to a very small extent due to a movement over a few myotomes which takes place chiefly near the time of metamorphosis, but is also due, and more largely, to the fact that there is little growth in the region of the dorsal fin, whilst the tail region increases to a much greater degree. Fage has shown that, like the Pilchard, the position of the pelvic fins depends on the 15th rib, and changes in the abdominal cavity affect slightly their position in the body. This movement causes them to be brought nearer to the dorsal fin by 1-2 myotomes. The growth of the tail region also affects the position of the anus, its change being due partly to this and to a slight extent to a migration over 4-5 myotomes.

It is here that my results differ slightly from those of Fage, for, as is shown above, the change of relative positions of the pelvics, dorsal fin, and anus can be accounted for by the actual change of position with regard to the myotomes, and not merely to the greater growth of the tail and abdominal regions, but the larger change of position of dorsal fin and anus which brings them nearer the head is, as Fage states, dependent much more on the increase of the tail region and the small growth of the region of the trunk.

The following measurements show the larger growth of the tail region :-

$\begin{array}{ccccc}A B & A D & D B & D \delta & \frac{A \delta}{\delta B} \\ 11.75 & 9 \cdot 25 & 2.5 & 0 & \frac{9 \cdot 25}{2 \cdot 5}=3 \cdot 7 \\ 24.5 & 17 & 7 \cdot 5 & 0 \cdot 75 & \frac{17 \cdot 75}{6 \cdot 75}=2 \cdot 6 \\ 41 & 25 & 16 & 2.5 & \frac{27 \cdot 5}{13 \cdot 5}=2 \cdot 0\end{array}$

$\delta$ being the imaginary position of the anus when corrected for shift in position.

The ratio $\frac{A \delta}{\delta B}$ decreases, showing that the distance $\delta B$ increases proportionately more than the distance $A \delta$. In the same way the growth of the tail region influences the position of the dorsal fin, the migration over the vertebræ and myotomes being only a very small factor in the change. 
At the time when the changes begin to take place prior to metamorphosis the dorsal fin and anus are almost in a straight line one above the other, and the pelvics are about two myotomes in front of the dorsal fin. The anus is now in its permanent position with regard to the myotomes, that is to say, it is in the region of the $32 \mathrm{nd}$ or $33 \mathrm{rd}$ vertebra. The dorsal fin, however, goes further after this, so that just before or during metamorphosis it is separated from the anus by two or more myotomes, and its final position is usually in connection with the 31st vertebra. It is thus at the time of general changes that the chief migration takes place in the dorsal fin, but as we have specimens undergoing metamorphosis still in the transparent post-larval condition at $41 \mathrm{~mm}$., we find that the changes begin about $32 \mathrm{~mm}$. and may continue until $41 \mathrm{~mm}$. On the other hand, the metamorphosis (if it be correct to call this gradual change a metamorphosis) may begin about $32 \mathrm{~mm}$. We have metamorphosed specimens as small as $30 \mathrm{~mm}$., and these have larger heads in proportion to those not metamorphosed, and have other points of difference. Thus in the Plymouth specimens, from 32 to $41 \mathrm{~mm}$., changes are taking place which lead to the scaled silvery stage, and at this time there is a much slower growth of the trunk compared with the head and tail, leading up to an almost complete cessation of growth at the actual time of metamorphosis, as is shown by Fage. I think it highly probable that in the Plymouth specimens there is an actual reduction in length, for the smallest metamorphosed forms are much further forward than any of the later post-larvæ of the same length, i.e. they are much pigmented, have scales, or the scales clearly marked out if not actually through the skin, a longer head and a longer tail, and the pelvic fins nearer to the dorsal, the dorsal fin and anus being practically in the adult position, although in some larger metamorphosed specimens it may be one myotome further forward. Moreover, if we take a post-larval and metamorphosed specimen of the same length, besides the difference in shape, longer head, presence of scales in the latter, we find that there are more myotomes in the same space in this than in the post-larval form. For instance, if the trunk measures $13 \mathrm{~mm}$. in a metamorphosed form, 16 in a post-larval form of $30.5 \mathrm{~mm}$., there are 31 myotomes in the trunk of the former, 34 in the latter, but if we measure $13 \mathrm{~mm}$. from the operculum in the post-larval form we find there are only 27 myotomes, showing that the myotomes are more crowded together in the metamorphosed form, and it is not until at least 33 or $34 \mathrm{~mm}$. that there are only 31 myotomes in the trunk of the post-larval forms.

In the metamorphosing Sprat from 32 to $41 \mathrm{~mm}$. we find the 7 pyloric cœea fully formed. Even at $26 \mathrm{~mm}$. there are 7, but only present as very minute buds. The ventral spinous scales are formed before the 
side scales, and begin as early as $35 \mathrm{~mm}$. in quite transparent postlarval specimens. From that time the body scales are outlined more or less, although they are not through the skin, and pigment begins externally along the sides and dorsal surface, although it is still quite unlike the final adult silvery state.

It is interesting to find in a large haul of thousands of these young Sprats, with a few Herring, that they are all in the post-larval stages, most of them metamorphosing, but none of them having actually metamorphosed, although ranging from under $30 \mathrm{~mm}$. to $41 \mathrm{~mm}$. in the Sprat, and from 35 to $48 \mathrm{~mm}$. in the Herring. This is probably due to the fact that after metamorphosis the silvery fish instantly congregate together, leaving those which are still transparent, and come closer inshore. Probably they would be too conspicuous to remain with the still more or less transparent forms. This is borne out by the fact of a large haul of Sprats from the Cattewater (1913), 30 to $50 \mathrm{~mm}$., consisting entirely of Sprats evidently only just metamorphosed, for although they have the adult proportions and pigment they are not yet properly silvery, the scales being still underneath the skin. Other hauls consist entirely of perfectly silvery specimens.

The measurements of the growth of the Sprat at different periods of its development agree with the observations of Fage who shows that the growth is different from that of the Pilchard in that in the postlarvæ the increase in growth is due about equally to head, trunk, and tail, whereas in the Pilchard the increase is due about as much to the trunk as to the head and tail together, but in both there is a cessation, or at any rate a great slackening of growth during metamorphosis, and after metamorphosis they are alike in the increase of the trunk, being about equal to that of the head and tail together. The only difference in the Plymouth specimens is that the larger post-larvæ, although slackening in trunk growth, do not so nearly stop, thus as the fish grows its trunk grows gradually less. From 31 to $39 \mathrm{~mm}$. in the post-larvæ the trunk has increased $2 \mathrm{~mm}$., but from a post-larval form of $31 \mathrm{~mm}$. to a metamorphosed form of $39 \mathrm{~mm}$. it has only grown $1.5 \mathrm{~mm}$, the head having increased 4.

If we now compare the Sprat and the Pilchard in the young stages we find them easy to differentiate up to the time of the loss of the yolk sac owing to the oil globule in the Pilchard. After that the only reliable distinguishing character up to the time of the appearance of the pelvic fins is the myotomes. It is easier to count the myotomes in the trunk than in the whole body, usually 37 in the Sprat, 42 in the Pilchard, reduced to 35 and 41 respectively up to $25 \mathrm{~mm}$. In the Plymouth specimens one can usually distinguish them by the more advanced state of development in the Sprat than in the Pilchard throughout its life, especially in the 
younger stages with regard to the fins, but as Fage finds this is the reverse in those which he describes it is evidently an unreliable character depending on the locality. The myotomes then are the safest guide up to the appearance of the pelvic fins, $17 \cdot 25-20 \mathrm{~mm}$. in the Sprat, 20-22 mm. in the Pilchard, when their position a few myotomes from the pylorus in the Sprat and on a level with it in the Pilchard clearly distinguish the species, as Fage discovered. The forward position of the pelvies in the Pilchard is also a distinguishing mark, the ratio of snout to pelvics and snout to total body length being about 43 in these early stages of the Pilchard and about 45 in the Sprat. In the later stages the relative position of the dorsal and pelvic fins and the position of the dorsal fin and anus relative to the body length clearly differentiate the species. The anus also in the Sprat is much closer to the dorsal fin than it is in the Pilchard, and near the time of the metamorphosis stands exactly, or almost exactly, underneath it.

\section{THE HERRING.}

\section{Clupea Harengus L.}

The eggs of the Herring occur on the sea bottom in bays close to the shore at Plymouth, Bigbury Bay and off Rame being favourite spawning grounds (Cunningham, 1896, and present records). The eggs measure 0.9 to $1.4 \mathrm{~mm}$. across, the newly hatched forms measuring $6-8 \mathrm{~mm}$. These latter begin to appear in the Sound in December (one newly hatched is recorded on October 10th), continue plentifully during January, dwindle in February, and usually disappear in March. The latest record for very young stages is one of $13 \mathrm{~mm}$., April 8th, 1914. The post-larval forms occur occasionally through the spring, but are rare in summer, the haul from Whitsand Bay, 30.6.06, containing several older post-larvæ from 30 to $48 \mathrm{~mm}$. No specimens were obtained between these and fully scaled metamorphosed forms from $55 \mathrm{~mm}$. which occurred with the Sprats and sometimes with the Pilchards near the shore and up the rivers.

The yolk sac may be absorbed as early as $8 \mathrm{~mm}$., but in the Plymouth specimens it is often present at $10 \mathrm{~mm}$., and remnants may even persist as late as $12 \mathrm{~mm}$. During the absorption of the yolk, however, the young Herring may be taking solid food, such as larval molluses, copepod eggs, and nauplii, and small cladocera. When the yolk sac has gone the dorsal fin begins to appear, but if the yolk sac be still present, even at a greater length, there is no trace of dorsal fin (Fig. 10).

The notochord is straight until at least $17 \mathrm{~mm}$., the smallest seen 
with the notochord turning up being $17 \cdot 25 \mathrm{~mm}$., but it is usually straight at $18 \mathrm{~mm}$., and only completely turned up at $21 \mathrm{~mm}$., or more.

The dorsal fin is complete as to its full number of rays at about $28-29 \mathrm{~mm}$. The hindmost fin ray is formed at about $18-19 \mathrm{~mm}$., when there are usually 7-8 myotomes between the anal fin and the last dorsal ray. The anal fin is complete soon after the dorsal, so that both are complete at $30 \mathrm{~mm}$. The number of rays in the Plymouth specimens (Orton, 1918) is usually 19 in the dorsal, but may vary from 17 to 21 , and 17 in the anal, rarely 15 to 19 . The pelvic fins do not begin to appear until 22 to $23 \mathrm{~mm}$. Fage shows that they occur a long distance
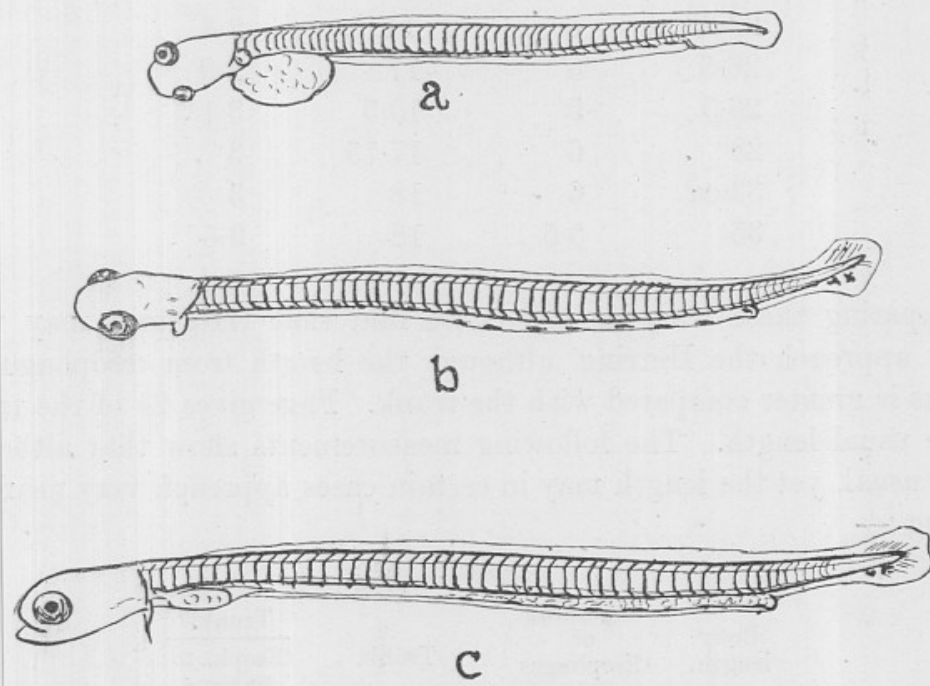

FIG. 10.-Newly hatched and very young Herring; $a$., newly hatched Herring, $7 \mathrm{~mm}$., Rame Head, N.N.W $3 \frac{1}{2}$ miles, midwater, 22.1.14; $b$., young Herring having lost its yolk sac, dorsal fin beginning, $9.5 \mathrm{~mm}$., Breakwater, 2.1.20; c., young Herring with yolk sac still present, $10.5 \mathrm{~mm}$., T.N., Penlee-Knap, 6.1.20.

from the pylorus, a character which is striking and easily differentiates the Herring from the Pilchard and Sprat. They are usually situated under the 24 th vertebra, about $7 \mathrm{~mm}$. from the first ray of the dorsal fin and near the beginning of the 24th myotome. The pylorus is far forward, but not so far forward in my specimens as it is in Fage's. This indeed is a rather striking difference between his and my specimens, and one which, as he regards it of sufficient importance to base part of his key upon, should have special stress laid on it.

Fage shows that the length from œsophagus to pylorus at $20.5 \mathrm{~mm}$. is contained at least 3 times and $\frac{1}{3}$ in the length of the trunk. I find that it is always longer than this in my specimens until a very much

\footnotetext{
NEW SERIES, - Vol. XII. No. 3. SEPTEMBER, $1921 . \quad 2$ F
} 
greater body length. The following measurements of nine specimens show that up to $23 \mathrm{~mm}$. or more it is contained under three times in the trunk, only at $35 \mathrm{~mm}$. does it approach $3 \frac{1}{3}$ :-

\section{Herring.}

\begin{tabular}{|c|c|c|c|}
\hline $\begin{array}{l}\text { Body } \\
\text { length. }\end{array}$ & $\begin{array}{l}\text { Beginning } \\
\text { of } \\
\text { Esophagus } \\
\text { to Pylorus. }\end{array}$ & Trunk. & $\begin{array}{l}\text { Trunk. } \\
\text { Esoph. to } \\
\text { Pylorus. }\end{array}$ \\
\hline $18 \cdot 75$ & 5 & 13 & $2 \cdot 6$ \\
\hline 21 & $5 \cdot 5$ & $14 \cdot 25$ & $2 \cdot 7$ \\
\hline $22 \cdot 5$ & $5 \cdot 25$ & 15 & $2 \cdot 8$ \\
\hline $22 \cdot 23 \mathrm{ca}$ & $5^{.}$ & 14 & $2 \cdot 8$ \\
\hline $26 \cdot 5$ & 6 & 17 & $2 \cdot 9$ \\
\hline $26 \cdot 5$ & 5 & $15 \cdot 5$ & $3 \cdot 1$ \\
\hline 28 & 6 & $17 \cdot 75$ & 3. \\
\hline $33 \mathrm{ca}$ & 6 . & 18 & 3 \\
\hline 35 & $5 \cdot 5$ & 18 & $3 \cdot 3$ \\
\hline
\end{tabular}

Comparing these with the Sprat we find that the Sprat may very nearly approach the Herring, although the length from œsophagus to pylorus is greater compared with the trunk. Fage gives $2 \frac{2}{5}$ of the trunk as the usual length. The following measurements show that although this is usual, yet the length may in certain cases approach very near the Herring :-

\begin{tabular}{|c|c|c|c|}
\hline $\begin{array}{l}\text { Body } \\
\text { length. }\end{array}$ & $\begin{array}{l}\text { Beginning } \\
\text { of } \\
\text { Esophagus } \\
\text { to Pylorus. }\end{array}$ & Trunk. & $\begin{array}{l}\text { Trunk. } \\
\text { CEsoph. to } \\
\text { Pylorus. }\end{array}$ \\
\hline $18 \cdot 5$ & 4.5 & $10 \cdot 5$ & $2 \cdot 3$ \\
\hline $19 \cdot 75$ & $4 \cdot 5$ & 11 & $2 \cdot 4$ \\
\hline $22 \cdot 5$ & 4 & 11 & $2 \cdot 7$ \\
\hline 23 & $4 \cdot 75$ & 12 & $2 \cdot 5$ \\
\hline 25 & $5 \cdot 5$ & $14 \cdot 5$ & $2 \cdot 6$ \\
\hline
\end{tabular}

The Pilchard is much the same as the Sprat, but keeps more regularly to the $2 \frac{2}{5}$ given by Fage :-

\section{Pilchard.}

\begin{tabular}{|c|c|c|c|}
\hline $\begin{array}{l}\text { Body } \\
\text { length. }\end{array}$ & $\begin{array}{l}\text { Beginning } \\
\text { of } \\
\text { Esophagus } \\
\text { to Pylorus. }\end{array}$ & Trunk. & $\begin{array}{l}\text { Trunk. } \\
\text { Esoph. to } \\
\text { Pylorus. }\end{array}$ \\
\hline $19 \cdot 5$ & 5 & $13 \cdot 5$ & $2 \cdot 5$ \\
\hline $22 \cdot 75$ & $5 \cdot 5$ & $13 \cdot 5$ & $2 \cdot 4$ \\
\hline $25 \cdot 5$ & 6 & $14 \cdot 5$ & $2 \cdot 4$ \\
\hline
\end{tabular}


The greater length of the fore part of the alimentary canal in the Plymouth Herrings is easily explained by the fact that the head is shorter and the trunk longer in these than in the northern forms, which is shown by Fage, and also that they develop more slowly also,

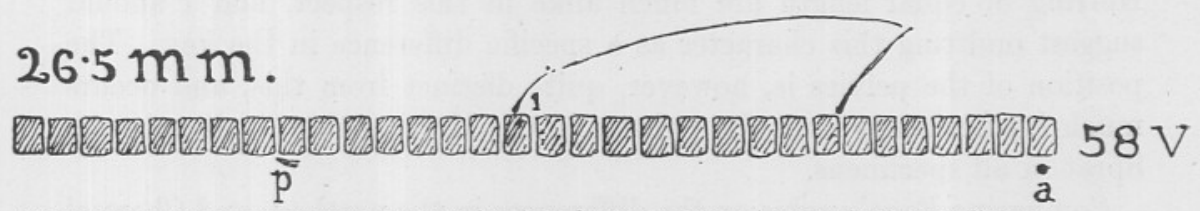

1819202122232425282728293031323334353637383940414243444546474849
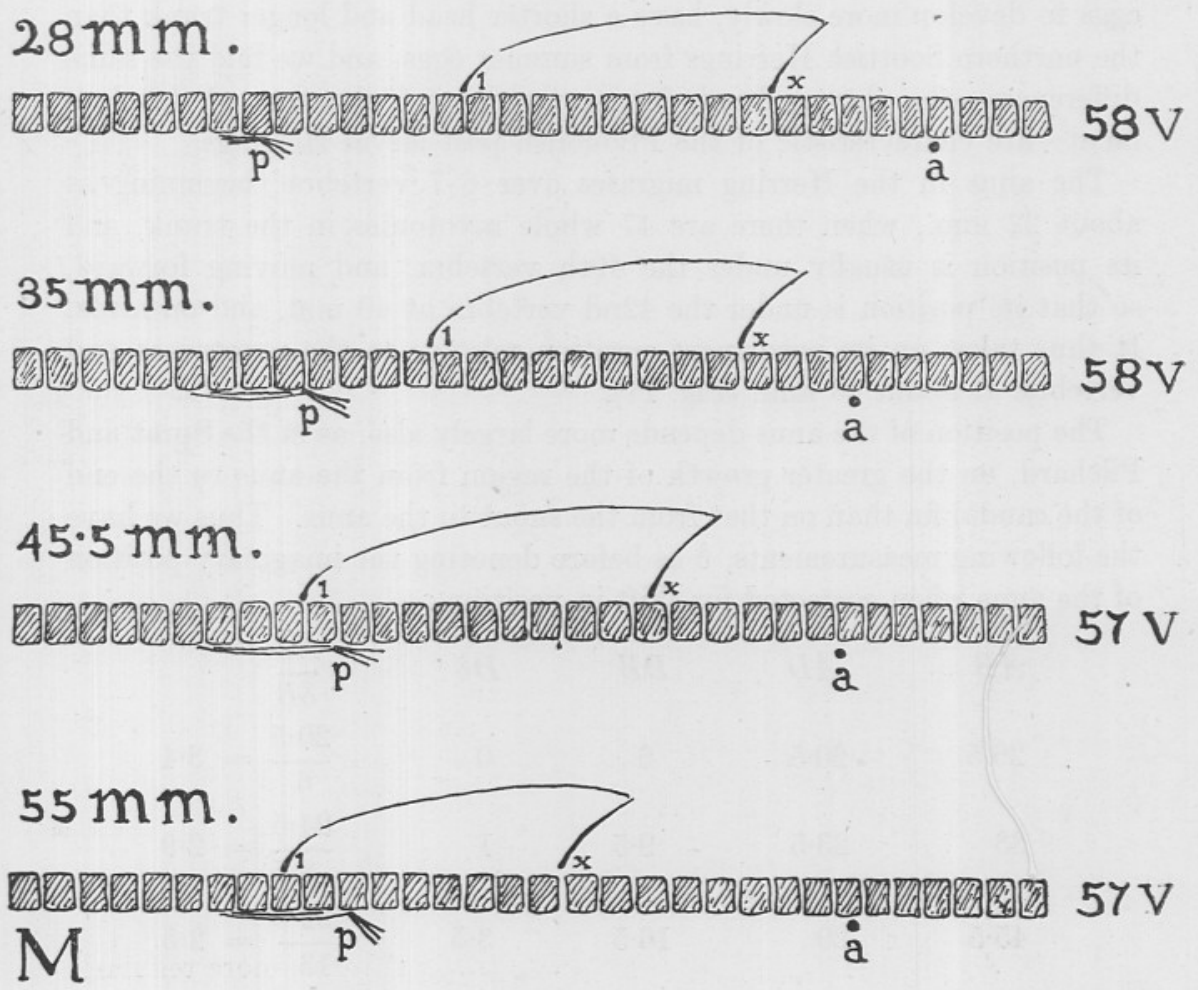

FIG. 11.-Showing the relations of the fins and anus to the vertebræ in the Herring of various lengths; $p$., pelvic fins; $1-x$., first and last rays of dorsal fin; $a$., anus; $v$., vertebræ; $m$., metamorphosed specimen.

as the front part of the alimentary canal increases much less than the hind part, the ratio of the trunk to the front part increases as the fish grows. In this way the desired ratio is reached much later in the Plymouth specimens than in those from the north. Comparing this with. the Sprat we have a similar decrease in the ratio as the fish grows. If, 
therefore, we have a very forward Sprat, as for instance the specimen of $22.5 \mathrm{~mm}$. measured above, the distance from œsophagus to pylorus is short compared with the intestine, and the ratio is similar to that of the Herring at $21 \mathrm{~mm}$. Thus the forward Sprat and the backward Herring of equal length are much alike in this respect, and I should suggest omitting this character as a specific difference in the key. The position of the pelvics is, however, quite distinct from this, and occurs much further away from the pylorus in the Herring than it does in the Sprat in all specimens.

Comparing Fage's notes on the differences in the northern and Channel forms (p. 114) we find that he shows the Channel forms from winter eggs to develop more slowly, have a shorter head and longer trunk than the northern Scottish Herrings from summer eggs, and we find the same differences - the shorter head, longer trunk, and slowness of development-are characteristic of the Plymouth post-larval Herrings.

The anus in the Herring migrates over 6-7 vertebræ, beginning at about $22 \mathrm{~mm}$., when there are 47 whole myotomes in the trunk, and its position is usually under the 49th vertebra, and moving forward, so that its position is under the $42 \mathrm{nd}$ vertebra at $40 \mathrm{~mm}$. and onwards. It thus takes up its permanent position relative to the myotomes and vertebræ at about $40 \mathrm{~mm}$. (Fig. 11).

The position of the anus depends more largely also, as in the Sprat and Pilchard, on the greater growth of the region from the anus to the end of the caudal fin than on that from the snout to the anus. Thus we have the following measurements, $\delta$ as before denoting the imaginary position of the anus when corrected for shift in position :-

$\begin{array}{lcccc}A B & A D & D B & D \delta & \frac{A \delta}{\delta B} \\ 26 \cdot 5 & 20 \cdot 5 & 6 & 0 & \frac{20 \cdot 5}{6}=3 \cdot 4 \\ 33 & 23 \cdot 5 & 9 \cdot 5 & 1 & \frac{24 \cdot 5}{8 \cdot 5}=2 \cdot 9 \\ 45 \cdot 5 & 29 & 16.5 & 3.5 & \frac{32 \cdot 5}{13}=2 \cdot 5\end{array}$

the ratio $\frac{A \delta}{\delta B}$ decreasing, showing that the distance $\delta B$ increases proportionally more than the distance $A \delta$.

A comparison with the curves (Fig. 12) will show that the alteration of position is mainly due to the increase in the tail region.

Similarly with the dorsal fin, the forward movement over the myotomes only begins about $27 \mathrm{~mm}$. and stops probably just before metamorphosis, which in the Plymouth specimen probably only begins shortly 


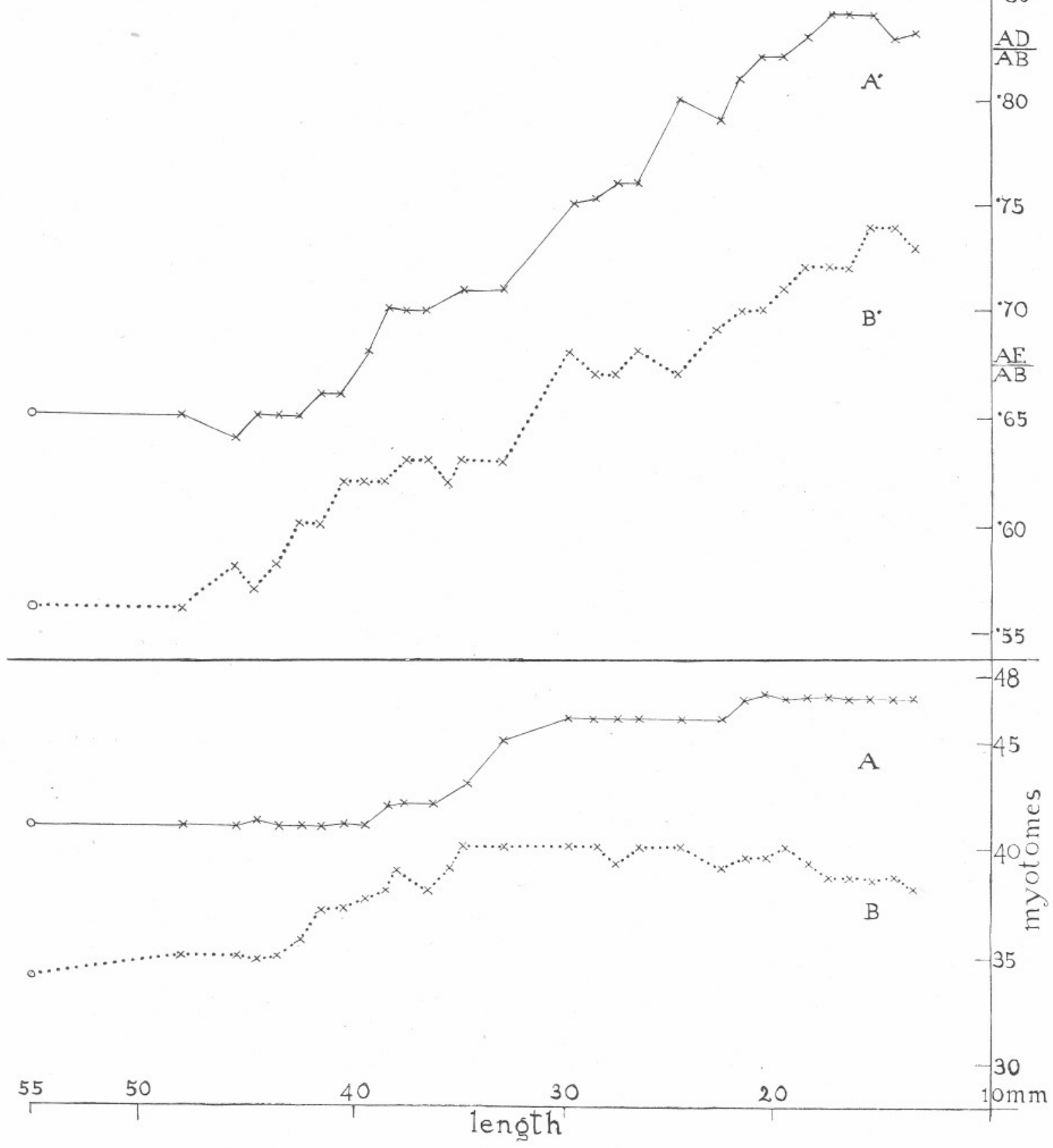

Fia. 12.-Curves showing the change of position of the dorsal fin and anus in the Herring; $A$, showing number of myotomes in the trunk in Herring, 13 to $55 \mathrm{~mm}$. long; $B$, showing number of myotomes between operculum and last ray of dorsal fin in same specimens; $A^{1}$, showing ratio of distance from snout to anus $(A D)$ and body length $(A B)$ in same specimen; $B^{1}$, showing ratio of distance from snout to last ray of dorsal fin $(A E)$ and body length in same specimens; $o=$ metamorphosed specimen. Correction for curve $A$ (approximate) to show true number of myotomes from head to anus. $+=$ myotomes covered by operculum. $-=$ myotomes overlapping anus : -13 to $27(+1), 27$ to $36(+1-1$ or -2$), 36$ to $46(+2-2)$. 
before $48 \mathrm{~mm}$. At this length the dorsal fin has not quite finished its migration and scales are indicated, but the proportions of the body are still those of the post-larva.

The hind end of the dorsal fin usually begins between the 42 nd and 43 rd vertebræ and the front ray over the $33 \mathrm{rd}$. The fin migrates over nearly eight vertebræ. It does not grow at a greater rate than the vertebræ as it does in the Sprat, so that with rare exceptions (when, as in the specimen of $45.5 \mathrm{~mm}$. in the diagram, over 10 vertebræ are involved) it extends over $9-10$ vertebræ. The final position of the fin, as shown in the small metamorphosed forms, is with its front ray over the 26 th vertebra, just behind the 25 th myotome, ${ }^{*}$ and the last ray between the 34 th and 35 th vertebræ. The pelvic fins originate under the 26 th vertebra, the rays finally taking up their position under the 28 th vertebra, about two myotomes behind the front of the dorsal fin. Transition stages after $48 \mathrm{~mm}$. are wanting, but in the specimens from 41 to $48 \mathrm{~mm}$. the scales are indicated as a slight pattern on the body, and the ventral keeled spines are developing. The pigment is also beginning along the lateral line and dorsally, but in shape the fish is still in a post-larval condition with a small head, and the dorsal and pelvic fins not yet in the final position. The smallest metamorphosed forms available measured $55 \mathrm{~mm}$. It is thus probable that at $48 \mathrm{~mm}$. the Plymouth specimens are not quite ready for metamorphosis, but nearly so. The pyloric cœca begin to develop as early as $33 \mathrm{~mm}$., and are very numerous at $43 \mathrm{~mm}$. Heincke $(1898$, p. 30 ) has shown that the autumn Herrings begin to metamorphose at $45-50 \mathrm{~mm}$., the metamorphosis being complete at $60 \mathrm{~mm}$., and ours seem to agree fairly well with this.

The method of growth of the post-larvæ up to about $41 \mathrm{~mm}$. is much the same as it is in the northern forms, but differing in that the trunk is longer in proportion to the head and tail. Thus we have the following measurements :-

Post-larvæ from 10.5 to $41 \mathrm{~mm}$., Plymouth.

$\begin{array}{lcrcr}\text { Length } & 10 \cdot 5 \mathrm{~mm} . & 41 \mathrm{~mm} . & & \\ \text { Head } & 1.5 & 7 & \text { increase } & 5 \cdot 5 \\ \text { Trunk } & 7.5 & 20 & , & 13 \cdot 5 \\ \text { Tail } & 1.5 & 7 & , & 5 \cdot 5\end{array}$

(anus to base of caudal fin)

Whilst from 41 to $48 \mathrm{~mm}$. we have :-

$\begin{array}{lrccc}\text { Length } & 41 & 48 & & \\ \text { Head } & 7 & 10 & \text { increase } & 3 \\ \text { Trunk } & 20 & 21 & , & 1 \\ \text { Tail } & 7 & 10 & , & 3\end{array}$

* Used in the true sense as elsewhere, except in the curves showing myotomes in trunk. 
Northern specimens (Fage, p. 115) :

$\begin{array}{lcrrr}\text { Length } & 10 \cdot 8 & 41 & & \\ \text { Head } & 1 \cdot 35 & 8 & \text { increase } & 6 \cdot 65 \\ \text { Trunk } & 7 \cdot 81 & 19 & \text { ", } & 11 \cdot 19 \\ \text { Tail } & 1 \cdot 72 & 8 & , & 6 \cdot 28\end{array}$

Thus up to $41 \mathrm{~mm}$. the same kind of growth is apparent, but the trunk is longer and the head shorter in the older Plymouth specimens. Fage has no specimens later than $41 \mathrm{~mm}$. from the "Thor," but ours show in those from 41 to $46 \mathrm{~mm}$. that growth in the trunk region is arrested as in the Sprat and Pilchard, so that there is only a growth of $1 \mathrm{~mm}$., whilst the head and tail have each increased 3.

\section{SUMMARY.}

In summing up the differences between the three species in their postlarval stages I am in complete agreement with Fage that the myotomes are the essential characters for the differentiation of the younger forms, but it is here proposed to use those from the operculum to the anus (the "trunk" region of Fage) as being more easily counted and more readily seen. Differences in rate of development are not good characters to distinguish between the Sprat and the Pilchard, as this differs with the locality, but the Herring is always much more backward in development for the same size than either the Sprat or the Pilchard. The length of the fore part of the alimentary canal also varies with locality, although it is shorter in the Herring than in the Pilchard and Sprat. When the pelvic fins appear (the length at which they appear varying slightly with the locality) the difference in position with regard to the pylorus is distinct, being on a level with the pylorus in the Pilchard, a slight distance from it in the Sprat and still further away in the Herring. Their position on the body is nearest the head in the Pilchard and usually furthest away in the Herring.

From the time that the pelvic fins appear the alteration in the position of the dorsal fin and anus makes the differentiation of the species still more easy, the anus coming to lie close up to the hind end of the dorsal fin in the Sprat and the migration of the dorsal fin being only very slight, whilst in the Herring it is considerable and in the Pilchard even greater, so that in these the anus lies far from the dorsal fin. The tail in the Sprat is the longest, in the Herring the shortest.

The Sprat metamorphoses at the smallest size, the Pilchard the next, and the Herring the greatest. The method of growth as Fage shows in the post-larval Sprat is different from that in the Pilchard and Herring, the increase in the trunk being about the same as in the head and tail, 
whilst in the Pilchard and Herring it is greater, the increase of the trunk being about equal to that of the head and tail together, there being a cessation of growth in the trunk in all three during metamorphosis, after which they all grow in the same way.

In order to utilize the key given by Fage and adapt it so that it embraces our own specimens it might be altered slightly, and applying it only to our three species herein treated, the Herring, Pilchard, and Sprat, use it as follows :-

Young 8-10 mm. long.

Distinguished by myotomes only.

Total number in body.

46-48

$51-52$

$56-58$
Number

in trunk.

usually 37 . . . . . Sprat

, $42 . \quad . \quad . \quad . \quad$. Pilchard

, 47 . . . . . Herring

$10-20 \mathrm{~mm}$.

Pelvic fins appear at $17 \cdot 5-20 \mathrm{~mm}$., some distance (4-5 myotomes) from the pylorus, 37-35 myotomes in trunk . Sprat

Pelvic fins appear at 18-22 mm., on a level with the pylorus, 42-41 myotomes in trunk . . . . . Pilchard

Pelvic fins not appeared, 47-46 myotomes in trunk . . Herring

20-40 $\mathrm{mm}$.

a. Pelvics on a level with the pylorus, 41-36 myotomes in trunk

Pilchard

b. Pelvics situated behind the pylorus :

(1) Length of tail * comprised well under 6 times in the total length, 35-31 myotomes in trunk

(2) Length of tail comprised more than 6 times in the total length, 46-41 myotomes in trunk. Pelvic fins situated 7-8 myotomes from pylorus

* The tail is here used in the same sense as given by Fage, i.e. from the anus to the base of the tail fin. 


\section{TABLE SHOWING RECORDS OF YOUNG HERRING, PILCHARD} AND SPRAT, ARRANGED IN MONTHS.*

(For chart of stations see Clark, 1914.)
$A=$ up to 10 fathoms inclusive.
$\mathrm{B}=>10$ to 20 fathoms inclusive.
$\mathrm{C}=>20$ to 30 fathoms inclusive.

$\mathrm{D}=$ over 30 fathoms.

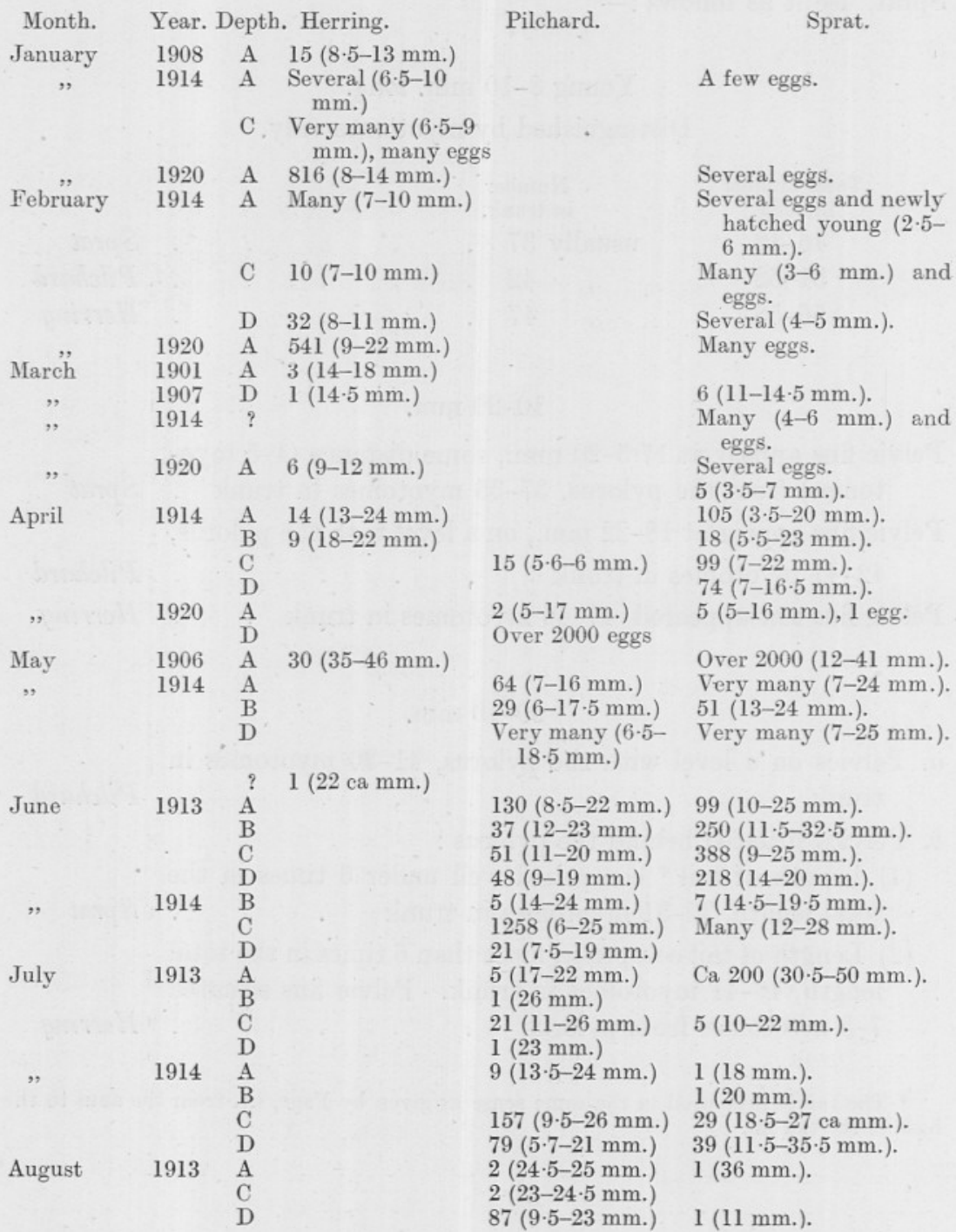

* For records in 1917-18-19, see Lebour $(1918,1919,1920)$ and Clark (1920). Further records for 1920 will be shortly published by Clark. 
Month. Year. Depth. Herring.

September $1913 \quad$ A

B

September $1914, \frac{D}{A}$

October $\quad 1913 \quad$ A

November $1913 \quad \stackrel{\text { C }}{\text { A }}$

\author{
Pilchard. \\ 70 (4.75-24 mm.). \\ $30(4.5-13 \mathrm{~mm}$.). \\ $148(3.5-23 \mathrm{~mm}$.). \\ and many eggs. \\ $10(6 \cdot 5-8 \mathrm{~mm}$.$) .$ \\ $1(24.5 \mathrm{~mm}$.). \\ $2(20 \cdot 5-22 \cdot 3 \mathrm{~mm}$.). \\ 7 (7-10 mm.). \\ $52(3 \cdot 5-13 \mathrm{~mm}$.). \\ several egge. \\ $343(5 \cdot 5-25 \mathrm{~mm}$.$) .$ \\ $27(5 \cdot 5-18 \mathrm{~mm}$.). \\ 4 (11-16 mm.). \\ $61(7-21 \mathrm{~mm}$.). \\ $1(13 \mathrm{~mm}$.).
}

Sprat.

LITERATURE.

1917. Allen, E. J. Post-larval Teleosteans collected near Plymouth during the Summer of 1914. Journ. Mar. Biol. Assoc., XI, N.S. 2.

1914. Clark, R. S. General Report on the Larval and Post-Larval Teleosteans in Plymouth Waters. Journ. Mar. Biol. Assoc., X, N.S. 2.

1920. - The Pelagic Young and Early Bottom Stages of Teleosteans. Journ. Mar. Biol. Assoc., XII, N.S. 2.

1889. Cunningham, J. T. Studies of the Reproduction and Development of Teleostean Fishes occurring in the Neighbourhood of Plymouth. Journ. Mar. Biol. Assoc., I, N.S.

1894. - The Life History of the Pilchard. Journ. Mar. Biol. Assoc., II, N.S.

1920. Fage, L. Engraulidæ, Clupeidæ. Report of the Danish Oceanographical Expedition, 1908-10, to the Mediterranean and the adjacent Seas. Vol. II, Biology A 9.

1910. Hefford, A. E. Notes on Teleostean Ova and Larvæ. Journ. Mar. Biol. Assoc., IX, N.S.

1898. Heincke, F. Naturgeschichte des Herings. Abhandl. d.d. Seefischeri Vereins, Bd. II.

1918-20. Lebour, M. V. The Food of Post-larval Fish, I, II, and III. Journ. Mar. Biol. Assoc., XI, No. 4 ; XII, Nos. I and II.

1916. Orton, J. H. An Account of the Researches on Races of Herrings carried out by the Marine Biological Association at Plymouth, 1914-15. Journ. Mar. Biol. Assoc., XI, 2. 